\title{
Responses of Soil Carbon, Nitrogen and Cations to the Frequency and Seasonality of Prescribed Burning in a Cape Cod Oak-Pine Forest
}

\author{
Christopher Neill ${ }^{1}$ \\ The Ecosystems Center, Marine Biological Laboratory, Woods Hole, MA 02543 \\ cneill@mbl.edu
}

William A. Patterson III

Department of Natural Resources Conservation

University of Massachusetts, Amherst, MA 01360

David W. Crary, Jr.

Cape Cod National Seashore, National Park Service, Wellfleet, MA 02667

1. Corresponding author and address

Keywords: fire frequency, fire season, pine barrens, sandplain, soil nutrients 


\begin{abstract}
Fire is an important component of the historic disturbance regime of oak and pine forests that occupy sandy soils of the coastal outwash plain of the northeastern U.S. Today prescribed fire is used for fuel reduction and for restoration and maintenance of habitat for rare plant, animal and insect species. We evaluated the effects of the frequency and seasonality of prescribed burning on the soils of a Cape Cod, Massachusetts coastal oak-pine forest. We compared soil bulk density, $\mathrm{pH}$ and acidity, total extractable cations and total soil $\mathrm{C}$ and $\mathrm{N}$ in unburned plots and in plots burned over a 12-year period, along a gradient of frequency (every 1to-4 years), in either spring (March/April) or summer (July/August). Summer burning decreased soil organic horizon thickness more than spring burning, but only summer burning every 1 to 2 years reduced organic horizons compared with controls. Burning increased soil bulk density of the organic horizon only in the annual summer burns and did not affect bulk density of mineral soil. Burn frequency had no effect on $\mathrm{pH}$ in organic soil, but burning every year in summer increased $\mathrm{pH}$ of organic soil from 4.01 to 4.95 and of mineral soil from 4.20 to 4.79. Burning had no significant effect on organic or mineral soil percent $C$, percent $N, C: N$, soil exchangeable $\mathrm{Ca}^{2+}, \mathrm{Mg}^{2+}, \mathrm{K}^{+}$or total soil $\mathrm{C}$ or $\mathrm{N}$. Overall effects of burning on soil chemistry were minor. Our results suggest that annual summer burns may be required to reduce soil organic matter thickness to produce conditions that would regularly allow seed germination for oak and for grassland species that are conservation targets. Managers may have to look to other measures, such as combinations of fire with mechanical treatments (e.g., soil scarification) to further promote grasses and forbs in forests where establishment of these plants is a high priority.
\end{abstract}




\section{Introduction}

Abundant charcoal in the sediments of Cape Cod ponds relative to other locations in New England indicates that fire was a persistent feature of these forests during 9,500 years of postglacial history (Winkler, 1985; Stevens, 1996; Fuller et al., 1998). European explorers of the New England coastline described pine forests with open, grassy, understories (Bromley, 1935; Altpeter, 1937), which they attributed to fires set by Indians (Day, 1953; Patterson and Sassaman, 1988). During the historical period, references to fire are frequent, and many large fires, particularly in cut-over or shrub-dominated landscapes, have been documented (Altpeter, 1937; Foreman and Boerner, 1981; Foster and Motzkin, 1999).

Since approximately 1940, fire suppression has reduced the number and extent of fires in northeastern oak-pine sandplain forests (Foreman and Boerner, 1981; Patterson et al., 1983; Dunwiddie and Adams, 1994; Motzkin et al., 2002). The elimination of burning is associated with changes to forest structure, including the gradual replacement of pines (Pinus rigida) by oaks (Quercus alba, Q. velutina, Q. coccinea, Q. ilicifolia and Q. prinoides) (Little 1964; Patterson et al., 1983, Chokklingam, 1995; Barron, 2005), an increase in the density of understory shrubs, including blueberries (Vaccinium spp.) and huckleberry (Galussacia baccata) (Little and Moore, 1949), and an increase in the thickness of the accumulated soil organic and litter layers (Little and Moore, 1949). A decrease in fire frequency is also associated with the loss of scrub oak (Q. ilicifolia) (Foster and Motzkin, 1999) and sandplain forbs typical of more open, savannah-like woodlands (Little and Moore, 1949; Dunwiddie, 1994; Clarke and Patterson, 2007). Fire maintained grasslands and recently-burned pitch pine-scrub oak communities are priorities for conservation in the northeastern U.S., because they are uncommon, declining, and support a number of rare plant and animal species (Schweitzer and Rawinski, 1988; Dunwiddie 
et al., 1996; Motzkin and Foster, 2002; Wagner et al., 2003). The historical role of fire, recent decreases in fire frequency, fire's association with rare species, and increased risk of large wildfires have led to calls for more prescribed burning for forest and rare species management in the coastal plain region (Patterson et al. 1985; Dunwiddie et al., 1997; Jordan et al., 2003).

Fire can lead to important changes in the physical and chemical properties of forest soils including increased bulk density and altered physical structure (Boyer and Miller, 1994; Arocena and Opio, 2003), increased soil cation stocks (Franklin et al., 2003; Liechty et al., 2005; Neff et al., 2005), and decreased carbon (C) and nitrogen (N) stocks in surface soils (Binkley, 1992; Choromanska and DeLuca 2001; MacKenzie et al., 2004; Shelburne et al., 2004). Responses of soil cations, $\mathrm{C}$ and $\mathrm{N}$ to fire vary substantially in direction, magnitude and the length of time during which changes can be detected after fire (Carter and Foster, 2004; Certini, 2005). The effects of prescribed surface fires on soils in many forest types are relatively minor (Richter, 1982; Boerner et al., 1988; Binkley, 1992; Ferran et al. 2005; DeLuca and Sala, 2006), but severe burns under drought conditions generally lead to significant changes to soil biogeochemical stocks (Southwick et al., 2005).

Most studies that have evaluated the effects of fires on forest soils have compared the effects of single wildfires or prescribed fires or the effects of a single prescribed fire regimei.e., the set of recurring conditions of fire that characterizes a given ecosystem. None have simultaneously evaluated the effects on soils of the frequency and the seasonal timing of fires that would allow determination of what fire regime would lead to important changes to soil chemistry and $\mathrm{C}$ and $\mathrm{N}$ stocks.

Prescribed burning has been used in sandplain oak-pine forests to reduce the competition of oaks with commercially valuable pines, to prepare the soil for pine seedling establishment and 
to reduce fire risk (Burns, 1952; Little, 1964; Dunwiddie and Adams, 1994; Patterson, 2007). Most prescribed burning for silvicultural purposes has been conducted during the spring, typically from March to May. Compared with intense wildfires, these understory fires do not typically damage trees $>2 \mathrm{~cm}$ dbh, recovery of shrubs is rapid (Reiners, 1965; Matlack et al., 1993), and effects on soil chemistry are minor (Burns, 1952). Understanding soil responses to prescribed fire in coastal plain forests is important, because the shrubs or herbaceous plants that are targets of conservation management involving prescribed fire often require specific conditions such as exposed mineral soil for germination (Dunwiddie, 1990; Vickery, 2002). In addition, most of the disturbance-adapted plant species that are conservation targets reach their greatest abundance on sites with low soil pH and low soil fertility (Dunwiddie et al., 1996; Neill et al., 2007).

We evaluated the effects of the frequency and seasonality of prescribed understory burning on the soils of a Cape Cod, Massachusetts coastal oak-pine forest. We compared soil bulk density, $\mathrm{pH}$ and acidity, total extractable cations and total soil $\mathrm{C}$ and $\mathrm{N}$ in control (unburned) plots and in plots subjected to prescribed burns, over a 12-year period, along a gradient of frequency (from 1-to-4 years) either in spring (March/April) or summer (July/August).

\section{Methods}

Study area

This study was conducted in the Lombard/Paradise Hollow research area of the Cape Cod National Seashore (CCNS), South Truro, Massachusetts $\left(41^{\circ} 57^{\prime} \mathrm{N}, 70^{\circ} 02^{\prime} \mathrm{W}\right)$. The area lies on coarse-textured glacial outwash deposits that are typical of the northeastern U.S. coastal plain (Oldale and Barlow, 1986). Soils are Typic Quartzipsamments of the Carver series (Fletcher, 
1993), with a coarse sand texture, an Oe horizon over a weakly-developed E horizon, and $<5 \%$ clay fraction (Fletcher, 1993). The area is $32 \mathrm{~m}$ above msl. Vegetation consists of a $\sim 90$-yearold, relatively even-aged canopy dominated by white oak (Q. alba), black oak (Q. velutina) and pitch pine ( $P$. rigida). The understory is dominated by the ericaceous shrubs black huckleberry (Galussacia baccata), early low and late low blueberry (Vaccinium angustifolium and V. pallidum). Soils and vegetation indicate the area was used continuously as a woodlot since European settlement (Dunwiddie and Adams, 1994). Similar oak-pine forests are the dominant vegetation on the northeastern US coastal plain.

A 5-ha area of relatively flat, uniform vegetation and soils was selected for prescribed burn treatments. Twenty-seven plots measuring $20 \mathrm{~m} \times 20 \mathrm{~m}$ were laid out in a random fashion (Patterson, 2007). Three replicate plots were assigned as either control (no burning), or spring (March or April) or summer (July or August) burning at frequencies of 1, 2, 3 or 4 years (Table 1). Plots were established in 1985 , with all but the control plots burned for the first time in March/April or July 1986. Plots were burned with strip-head fires with flame lengths in the initial fires of 1.5 to $2.25 \mathrm{~m}$. The Keetch-Byram Drought Index (KBDI) was used to estimate cumulative moisture deficiency in the duff and upper soils layer (Keetch and Byram, 1968; Melton, 1989). We used data on temperature, humidity and rainfall from climate stations on Cape Cod to calculate KBDI for each summer burn date.

\section{Sample collection and analysis}

Soils in all treatments were sampled in March of 1999 after 13 burns in the 1-year plots, 7 burns in the 2-year plots, 5 burns in the 3-year plots and 4 burns in the 4 -year plots. The timing of sampling was chosen because all plots were burned in either April or July 1998, and time since burning was similar in all treatments. Soil was collected at 3 randomly selected points in 
each plot excluding a $2 \mathrm{~m}$ buffer around the plot edge. At each point, 2 adjacent cores to $20 \mathrm{~cm}$ total thickness were collected using a 5-cm diameter steel corer after removal of the liter (Oi) horizon. Cores were extruded in the field, and the thickness of the duff layer (Oe horizon) was measured to the nearest millimeter in the resulting hole. The organic and mineral soil layers from each of the two adjacent cores from each point were combined and homogenized by thorough hand mixing. This yielded three composite organic and three mineral samples per plot and a total of 9 samples per soil horizon per treatment.

In the laboratory, a subsample was oven dried to determine dry bulk density. Soil samples were air dried and sieved through a $2 \mathrm{~mm}$ sieve to remove stones. Soil $\mathrm{pH}$ was measured in water (2:1, soil:water) on air-dried soil with an Orion 611 meter. Exchangeable $\mathrm{Ca}, \mathrm{Mg}$ and $\mathrm{K}$ in ovendry $\left(60^{\circ} \mathrm{C}\right)$ soil were measured by extraction with $1 \mathrm{~N} \mathrm{NH}_{4} \mathrm{Cl}$ (Robarge and Fernandez, 1986). Concentrations in the extracts were analyzed on a Perkin-Elmer atomic absorption spectrophotometer. Exchangeable acidity and exchangeable Al (to determine total cation exchange capacity to calculate percent base saturation) were measured on oven-dry soils by extraction with an unbuffered salt solution of $1 \mathrm{~N} \mathrm{KCl}$ and titration of the extract to the phenolpthalein titration end point (Robarge and Fernandez, 1986). Concentration of Al in the extracts was analyzed by atomic absorption spectrophotometry.

Total $\mathrm{C}$ and $\mathrm{N}$ in organic and mineral soils were analyzed by grinding oven dry $\left(60^{\circ} \mathrm{C}\right)$ soils with mortar and pestle and combusting them in a Perkin-Elmer 2400 elemental analyzer. Total soil $\mathrm{C}$ and $\mathrm{N}$ were calculated from percent $\mathrm{C}$ and $\mathrm{N}$ and soil bulk density for each horizon. Changes to total $\mathrm{C}$ and $\mathrm{N}$ relative to the control caused by the various burning treatments were estimated by calculating $\mathrm{C}$ and $\mathrm{N}$ mass to the same depth in the mineral horizon that would have been sampled if there had been no decrease in volume of the organic horizon caused by burning 
(Davidson and Ackerman, 1993). In this case, this was $15.4 \mathrm{~cm}$ of the mineral horizon, which represented the mean mineral horizon sampled in the control, where the mean organic horizon (Oe) thickness was $4.6 \mathrm{~cm}$.

We used analysis of variance (GLM procedure of SAS) to test for differences in soil variables among treatment means and the effects of the season and frequency of burning. The mean of each soil parameter from the 3 replicate composite samples within each plot served as the input to the analysis. We first performed an overall test for the presence of any treatment effect using a one-way analysis with the 9 treatments as main effects $(\mathrm{df}=8,18)$. If any significant treatment effect was found, we then: 1) tested for differences among individual means using the Ryan-Einot-Gabriel-Welsch Multiple Range Test (REGWQ option in SAS), and 2) performed a second two-way ANOVA with burn season (spring or summer) and frequency $(1,2$, 3 or $4 \mathrm{yr}$ intervals $)$ as main effects $(\mathrm{df}=7,16)$. The level of significance was adjusted to account for the performance of multiple ANOVAs. We report means $\pm \mathrm{SE}$.

\section{Results}

Summer moisture conditions as indicated by the KBDI varied from 145 in the 1-year and 2-year burns in 1989 to 495 in the 1-yr burns in 1991 (Table 2). The mean KBDI across all years of the study was highest (327) in the 1-year burns and lowest (211) in the 4-year burns. The 1year treatments were burned 8 times when the KBDI exceeded 300 and 4 times when it exceeded 450. Only two of the 3-year and one of the 4-year treatments were conducted when the KBDI exceeded 300.

Burning significantly reduced the thickness of the organic horizon (Table 3), but only summer burning every 1 or 2 years reduced organic horizon thickness compared with the control (Fig. 1). Summer burning reduced organic horizon thickness to a greater extent than spring 
burning (Table 4). While organic matter thickness generally declined with increasing burning frequency, this effect was not significant (Table 4). The overall reduction in organic horizon thickness caused by the most severe burn treatment (summer burning every year) was from 4.6 to $1.9 \mathrm{~cm}$ (Fig. 1). Burning significantly increased the bulk density of organic soil (Table 3). This effect on bulk density was caused by higher density of organic soil with annual summer burning (Fig. 1). Both burning season and burning frequency significantly increased organic soil bulk density, and the interaction of season and density was significant (Table 4). The primary effect was greater density in the annual spring burns. Burning had no effect on the bulk density of mineral soil (Table 3$)$.

Burning significantly increased the $\mathrm{pH}$ of both organic and mineral soil (Table 3). In organic soil, $\mathrm{pH}$ increased from a mean of $4.01 \pm 0.07$ in the control to a mean of $4.51 \pm 0.04$ across all of the burn treatments (Fig. 2), but only the 1-year summer burns had higher $\mathrm{pH}$ than the control (Fig. 1). Neither season of burning nor frequency of burning had significant effects on organic soil $\mathrm{pH}$, but the interaction of interaction of season and frequency was significant (Table 4), and increased burning frequency increased organic soil $\mathrm{pH}$ more in the summer burns than in the spring burns (Fig. 2). Mean organic soil pH did not differ between spring burns (4.57 $\pm 0.05)$ and summer burns $(4.45 \pm 0.07)$. The $\mathrm{pH}$ of mineral soil in the control $(4.20 \pm 0.05)$ was similar to the $\mathrm{pH}$ of organic soil $(4.01 \pm 0.07)$ and the response of mineral soil $\mathrm{pH}$ to burning was very similar to that of organic soil (Fig. 2). Burning increased mineral soil $\mathrm{pH}$ to a mean of 4.43 \pm 0.03 across all burn treatments, but only the 1 -year summer burns had higher mineral soil $\mathrm{pH}$ than the control. Neither burning season nor burning frequency had significant effects on mineral soil $\mathrm{pH}$, but the interaction of season and frequency was significant (Table 4). Increased burning frequency increased mineral soil $\mathrm{pH}$ in the summer burns but not in the spring burns (Fig. 2). 
Burning reduced total exchangeable acidity in organic soil but had no effect in mineral soil (Table 3). Acidity in the 4-year spring burns and the 1-year summer burns was significantly lower than in the control (Fig. 2), and there were no consistent effects of season or frequency on organic soil acidity (Table 4). Treatment had no significant effect on $\mathrm{Ca}^{2+}, \mathrm{Mg}^{2+}$ or $\mathrm{K}^{+}$ concentrations or percent base saturation in either organic or mineral soil (Table 3).

Burning treatments had no significant effect on total exchangeable $\mathrm{Ca}^{2+}, \mathrm{Mg}^{2+}$ or $\mathrm{K}^{+}$in the top $20 \mathrm{~cm}$, though there was a general pattern of higher total exchangeable $\mathrm{Ca}^{2+}$ and lower total exchangeable $\mathrm{Mg}^{2+}$ and $\mathrm{K}^{+}$with burning (Fig. 3). The largest gains in exchangeable $\mathrm{Ca}^{2+}$ between the burned plots and the control $\left(7.0\right.$ to $\left.7.6 \mathrm{~g} \mathrm{Ca}^{2+} / \mathrm{m}^{2}\right)$ were in the 4-, 3-, and 2-year spring burns. Greatest losses of $\mathrm{Mg}^{2+}\left(4.2 \mathrm{~g} \mathrm{Mg}^{2+} / \mathrm{m}^{2}\right)$ were in the 1-year summer burn plots, and the greatest losses of $\mathrm{K}^{+}\left(5.0 \mathrm{~g} \mathrm{~K}^{+} / \mathrm{m}^{2}\right)$ were in the 2-year summer burn plots (Fig. 3).

Soil percent $\mathrm{C}$ in the organic and mineral horizons did not differ significantly among treatments (Table 3, Fig. 4). The largest effect of any treatment on percent soil C was lower soil percent $\mathrm{C}$ with annual summer burning. There was no effect of the treatments on soil $\mathrm{C}: \mathrm{N}$ (Table 3, Fig. 4). Differences in the total soil $\mathrm{C}$ at $0-20 \mathrm{~cm}$ among the individual treatments were not significant, but there was a pattern of lower total soil $\mathrm{C}$ with increased burning in summer (Fig. 4). Losses of $\mathrm{C}$ in the organic horizon of the treated plots compared with the control ranged from 2 to $21 \%\left(-0.06\right.$ to $\left.-0.68 \mathrm{kgC} / \mathrm{m}^{2}\right)$ in the spring burned treatments and from 20 to $50 \%$ (-0.64 to $\left.1.63 \mathrm{kgC} / \mathrm{m}^{2}\right)$ in the summer burned treatments. Changes to $\mathrm{C}$ stocks were more variable in the mineral horizon. In the spring treatments, changes ranged from a gain of $35 \%$ to a loss of $10 \%$ $\left(0.44\right.$ to $\left.-0.19 \mathrm{kgC} / \mathrm{m}^{2}\right)$, whereas in the summer treatments they ranged from a gain of $16 \%$ to a loss of $36 \%\left(+0.23\right.$ to $\left.-0.50 \mathrm{kgC} / \mathrm{m}^{2}\right)$. Highest $\mathrm{C}$ losses within each seasonal burn treatment occurred in the plots burned every year. 
Total soil N showed a similar pattern (Fig. 4), with no significant effect of the individual treatments but a similar pattern of lower total soil $\mathrm{N}$ with increased burning frequency in summer. Losses of $\mathrm{N}$ in the organic horizon of the treated versus the control plots ranged from 0 to $20 \%\left(-0.01\right.$ to $\left.-20.4 \mathrm{gN} / \mathrm{m}^{2}\right)$ for the spring and from 20 to $37 \%\left(-20.0\right.$ to $\left.-36.9 \mathrm{gN} / \mathrm{m}^{2}\right)$ for the summer. In mineral horizon, changes to $\mathrm{N}$ stocks relative to the control for the spring treatments ranged from a gain of $23 \%$ to a loss of $3 \%\left(-1.2\right.$ to $\left.8.8 \mathrm{gN} / \mathrm{m}^{2}\right)$, whereas for the summer burns changes ranged from a gain of $13 \%$ to a loss of $39 \%\left(4.8\right.$ to $\left.-14.8 \mathrm{gN} / \mathrm{m}^{2}\right)$.

\section{Discussion}

Prescribed burning across a wide range of frequencies and burning conducted in the dormant (spring) versus growing (summer) seasons had relatively minor effects on soil $\mathrm{pH}$, acidity, total exchangeable cations and total soil $\mathrm{C}$ and $\mathrm{N}$. Only the plots burned every 1-2 years in summer had higher $\mathrm{pH}$ and only the plots burned annually in summer had higher bulk density than the unburned controls. This indicated that only very frequent annual or biannual burning of the understory litter and shrubs in these forests caused appreciable change in these soil characteristics. This result was consistent with studies in southern loblolly pine forests (Richter, 1982; Binkley, 1982), ponderosa pine forests (Covington and Sackett, 1986; Wright and Hart, 1997; Gundale et al., 2005; Hatten et al., 2005) and oak forests (Boerner et al., 1988; Ferran et al., 2005), all of which showed no or relatively little change in soil $\mathrm{pH}$, cation or total soil $\mathrm{C}$ and $\mathrm{N}$ in response to single or repeated burning. In New Jersey pine-oak woodlands, Burns (1952) found fire rotations of 4 years increased extractable base cations only slightly. In the most extreme case, 35 years of annual burning of a Tennessee oak forest led to increased mineral soil bulk density and $\mathrm{C}$ concentration but not to a change to total C (Phillips et al., 2000). 
Frequent burning during summer had the largest effect on the thickness of the soil organic horizon. Although burning reduced the thickness of the organic soil and summer burns caused greater reduction in organic soil thickness than did spring burns, none of the treatments eliminated the organic horizon. Only in the 1-year summer burns, which reduced the mean organic horizon thickness from 4.6 to $1.9 \mathrm{~cm}$, was there an increase in bulk density of the organic horizon indicating a replacement of organic matter with mineral material. Mineral soil was exposed over as much as $50 \%$ of the area in these 1-year burn plots. A lack of change in bulk density with the other treatments indicated that the mineral composition of the organic horizon was relatively unaffected by burning. This absence of a change in soil bulk density was consistent with other studies of effects of fire on soils in pine or oak woodlands (Burns, 1952; Shelbourne et al., 2004, Rhoades et al., 2004). In New Jersey pine-shrub oak woodlands, Lutz (1934) reported that fires at 8- 12- and 16-year intervals had no significant effect on soil physical or chemical properties.

Summer burning may have led to the greatest changes in soil organic matter thickness, bulk density and $\mathrm{pH}$ because the greater frequency of fire increased the likelihood that fire occurred under conditions of soil drought. Burning under soil drought conditions results in greater fuel consumption (Sparks et al., 2002). This may be primarily for the primary cause of changes to soil pH, nutrients and organic matter. In 1987, the 1-year burns were conducted when KBDI was the highest at any time during the study (488) but no other treatments were burned in that year (Table 2). The frequency of burns with high KBDI might also be important, and burning in the 1-year burns was conducted more frequently (4 times compared with 1 time in any of the other treatments) during periods of drought conditions with KBDI $>450$ (Table 2). The effect of drought was more likely to be important in the summer burns compared with the spring 
burns, because the KBDI during spring burns never exceeded 200 and commonly was less than 100 (Patterson, unpublished data). Burns under these conditions consume little soil organic matter (Melton, 1989).

Carbon and $\mathrm{N}$ in the organic horizon comprised the majority of total soil $\mathrm{C}$ and $\mathrm{N}$ and accounted for most of soil $\mathrm{C}$ and $\mathrm{N}$ losses. Losses of $\mathrm{C}$ and $\mathrm{N}$ from the organic horizon were variable but tended to be greater with summer burning than with spring burning. Although summer burning decreased organic horizon soil $\mathrm{C}$ by 20 to $50 \%$ and organic horizon soil $\mathrm{N}$ by 20 to $37 \%, \mathrm{C}$ and $\mathrm{N}$ losses from the mineral horizon greater than $20 \%$ occurred only where severe burning occurred frequently (i.e., with high KBDI in the 1-year summer burns). Volatilization of soil $\mathrm{C}$ and $\mathrm{N}$ in the spring burning treatments was limited by higher soil moisture and generally higher fuel moisture contents during spring compared with summer (Patterson, unpublished data). Some of the spring-burned treatments (every 1, 2 and 3 years) and summer-burned treatments (every 2 and 3 years for $\mathrm{C}$, every 3 years for $\mathrm{N}$ ) actually had higher mineral total soil $\mathrm{C}$ and $\mathrm{N}$ than the unburned controls, presumably because of downward translocation from the organic horizon in these sandy soils.

We did not directly measure rates of soil $\mathrm{C}$ accumulation that could be compared against soil C losses, but the development of organic horizons of 4-to- $8 \mathrm{~cm}$ in a similar 60 - to 80 -yearold coastal plain second-growth mixed white oak (Q. alba) and black oak (Q. velutina) forest on Martha's Vineyard (Neill, unpublished data) suggests that rates of $\mathrm{C}$ accumulation in the organic horizon is in the range of 0.05 to $0.13 \mathrm{kgC} / \mathrm{m}^{2} / \mathrm{yr}$. At these rates, the C loss of $2.13 \mathrm{~kg} / \mathrm{ha}$ caused by the severest treatment of 12 years of annual summer burning would be replaced after 16 to 43 years without fire. Based on the same assumptions, regional $\mathrm{N}$ accumulation of 1.5 to $4 \mathrm{gN} / \mathrm{m}^{2} / \mathrm{yr}$ and a loss of $52 \mathrm{~g} \mathrm{~N}$ in the 1-year summer burns, could be replaced after 13 to 35 years without 
fire. Current rates of annual atmospheric $\mathrm{N}$ deposition for Truro, MA are approximately 1.23 $\mathrm{gN} / \mathrm{m}^{2}$ (Bowen and Valiela, 2001; NADP, 2006) and can account for 30 to $80 \%$ of the forest soil $\mathrm{N}$ accumulation. The annual deposition of $\mathrm{Ca}$ for the same location is $1.56 \mathrm{~kg} \mathrm{Ca} / \mathrm{ha} / \mathrm{yr}$ (NADP, 2006). This compares with measured gains of between 0.9 to $6.3 \mathrm{~kg} \mathrm{Ca} / \mathrm{ha} / \mathrm{yr}$ in the soils of the burned treatments. Deposition of Mg is $2.40 \mathrm{~kg} / \mathrm{ha}$ compared with losses of 0.1 and $4.2 \mathrm{~kg} / \mathrm{yr}$ in the burned treatments, and deposition of $\mathrm{K}$ is $0.72 \mathrm{~kg} \mathrm{~K} / \mathrm{ha}$ compared with losses of 1.4 to 5.0 $\mathrm{kg} / \mathrm{ha} / \mathrm{yr}$. This suggests that deposition alone could replace losses of Mg in 1-to-24 years, but replacement of lost $\mathrm{K}$ would take 23 to 83 years.

The effects of burn-induced losses of $\mathrm{Mg}$ and $\mathrm{K}$ of this magnitude are not known. Rates of biomass accumulation in mesic New England oak and pine forests are thought to be most strongly influenced by soil available N (Aber et al. 1993). However, Woodwell (1979) suggested that repeated burning of Long Island oak and pine forest that reduced total ecosystem cation content to $60 \%$ of that in unburned forest was associated with reduced forest productivity and forest stature. Potassium additions to red pine (Pinus resinosa) plantations on acid, coarsetextured soils in New York State increased tree growth and crown vigor (Heiberg et al., 1964) and high K retention (Stone and Kszystyniak, 1977), indicating a strong link between K availability and forest growth.

\section{Prescribed burning in conservation and restoration management}

The spring prescribed burn treatments were likely typical of many of the historical wildfires in coastal oak and pine forests, including those ignited by Native Americans, who often set fires in the fall, or before leaf emergence in the spring (Patterson and Sassaman, 1988). Our results showed spring fires caused relatively minor changes to soil organic matter, structure, exchangeable cations and total soil $\mathrm{C}$ or $\mathrm{N}$. They also caused less tree mortality than summer 
fires, and that which did occur was largely attributable to our more intense initial burns (Patterson, 2007). There is some evidence from the edaphically and floristically similar New Jersey pine barrens that repeated, light, dormant-season fires reduce huckleberry dominance and promote the growth of understory herbs (Buell and Cantlon, 1953; Little, 1974; Little, 1979). With the exception of the 1-year burns, our results were more like those of studies of oak woodlands in Wisconsin (Reich, 1990; King, 2000), Kansas (Abrams, 1988) and Minnesota (White, 1983) where single spring or fall burns had very little effect on vegetation composition (Patterson, 2007).

While the response to spring burning suggests that the fire regimes employed in this study may be relatively good surrogates for historical spring wildfires across widespread oakpine forests in this landscape, our prescribed summer fires were almost certainly not precise analogues for the occasional large summer fires that are known to have occurred in these coastal forests (Altpeter, 1937; Patterson et al., 1983; Foster and Motzkin, 1999). Historical summer wildfires would likely have been more severe, because they would almost always have occurred under extreme drought conditions. Burning on our small plots prevented the development of high intensity surface and crown fires. However, the increased frequency of summer burns did increase the likelihood that one of our fires would burn at a KBDI $>300$ when organic soils are dry and the consumption of soil organic matter greatest (Melton, 1989). Thus, even though our fires were not crown fires with high intensity, they were sometimes duff-consuming ground fires of high burn severity that consumed soil organic matter. Unlike spring burns, summer burns occurring when KBDI values were high drastically altered vegetation on the forest floor. They also caused higher mortality of oaks (Patterson, 2007) and would have caused higher mortality of pines if they had evolved into crown fires. 
The response of oak-pine woodland soils to frequent prescribed understory fire raises the interesting question of whether alterations to the soil organic horizon are sufficient to enhance the recruitment of herbaceous plant species that occur in barrens and are targets for conservation management (Clarke and Patterson, 2007). Recruitment of some species, such as crowberry (Corema conradii), bushy rockrose (Helianthemum dumosum) and New England blazing star (Liatris scariosa var. novae-angliae) is enhanced by burning (Dunwiddie, 1990; Vickery, 2002). None of our spring burn treatments eliminated surface soil organic matter, and only the annual summer burns reduced organic matter thickness sufficiently to expose mineral soil. Although the life history and seed germination requirements of many rare sandplain herbaceous plants are not well known (Farnsworth, 2007), our results suggest that severe burning sometimes associated with summer burns may be required to produce conditions that would allow recruitment of many of these species. In the annual summer burn plots, pitch pine seedlings have germinated in some years, consistent with the results of intense prescribed burns (Little 1964) or wildfires (Landis et al., 2005) in pine barrens, but these seedlings do not survive burns repeated at 1- to 4- year intervals as applied in this study (Patterson, unpublished data). Proximity of seed sources may be an important constraint to vegetation change in oak forests even if prescribed fires result in appropriate seed bed conditions (Matlack and Good, 1990; Farnsworth, 2007). Seed augmentation may be a practical way to encourage herbaceous plant recruitment after disturbances which expose mineral soil in these forests (Lezberg et al., 2006).

Our results also raise the question of whether the losses in soil $\mathrm{C}$ or exchangeable $\mathrm{Mg}^{2+}$ and $\mathrm{K}^{+}$that accompanied frequent summer burning are sufficient to promote species-rich, oakpine "barrens" vegetation (Swain and Kearsly, 2001). Many native sandplain species reach their greatest abundance on sites with low $\mathrm{pH}$, low organic matter and low cation stocks (Dunwiddie 
et al., 1996; Neill et al., 2007). The levels of soil C and nutrient impoverishment that favors these species is not known, but nutrient removal by fire is used to reduce nutrient stocks in similar barrens and heathland vegetation (Tiffney, 1997; Mitchell et al., 2000). The relatively inefficient nature of prescribed burning at all but the most frequent intervals on altering soil $\mathrm{C}$ and nutrient stocks suggests that managers may have to look to other, more extreme measures of nutrient removal on sites where reestablishment of sandplain forbs and grasses is a high priority. Although summer burning under severe drought conditions, which produces abundant smoke over prolonged periods, is impractical in the coastal plain where residential development is increasing (Stone, 1998), burning combined with mechanical soil scarification and/or grazing may be an effective method of promoting rare plant habitat (Patterson and Clarke, in press).

\section{Acknowledgments}

We thank Jimmy Byun, Elizabeth Carpino and Suzanne Thomas for help with soil sampling and analysis, and Erin Shanley who compiled KBDI data for the study period. We thank the staff of the Cape Cod National Seashore for their help in establishing and maintaining the experimental plots. Funding was provided by the National Park Service, The Nature Conservancy via a grant from the Mellon Foundation, the Joint Fire Science Program, and a grant from the Mellon Foundation to MBL. We thank Tom Chase, Mark Abrams, and two anonymous reviewers for comments on earlier drafts of the manuscript.

\section{References}

Aber, J.D., Magill, A., Boone, R., Melillo, J.M, Steudler, P., 1993. Plant and soil responds to chronic nitrogen additions at the Harvard Forest, Massachusetts. Ecol Appl. 3, 156-166. Abrams, M.D., 1988. Effects of prescribed fire on woody vegetation in a gallery forest understory in northeastern Kansas. Trans. Kansas Acad. Sci. 91, 63-70. 
Altpeter, L.S., 1937. A history of the forests of Cape Cod. M. S. Thesis, Harvard Univ., Cambridge, MA. 69 pp.

Arocena, J.M., Opio, C., 2003. Prescribed fire-induced changes in properties of sub-boreal forest soils. Geoderma 113, 1-16.

Barron, E.S., 2005. Forest stand dynamics and plant succession in upland communities of Cape Cod National Seashore. M.S. Thesis, University of Massachusetts, Amherst, MA. 93 pp. Binkley, D., Richter, D., David, M.B., Caldwell, B., 1992. Soil chemistry in a loblolly/longleaf pine forest with interval burning. Ecol. Appl. 2, 157-164.

Boerner, R. J., Lord, T.R., Peterson, J.C., 1988. Prescribed burning in the oak-pine forest of the New Jersey pine barrens: effects on growth and nutrient dynamics of two Quercus species. Am. Midl. Nat. 120, 108-119.

Bowen, J.L., Valiela, I., 2001. Historical changes in atmospheric nitrogen deposition to Cape Cod, Massachusetts, USA. Atmos. Environ. 35, 1039-1051.

Boyer, W.D., Miller, J.H., 1994. Effect of burning and brush treatments on nutrient and soil physical properties in young longleaf pine stands. For. Ecol. Manage. 70, 311-318.

Bromley, S.W., 1935. The original forest types of southern New England. Ecol. Monogr. 5, 6189.

Buell, M.F., Cantlon, J.E., 1953. Effects of prescribed burning on ground cover in the New Jersey pine region. Ecology 34, 520-528.

Burns, P.Y., 1952. Effect of fire on forest soils in the Pine Barren region of New Jersey. Yale School Forestry Bull. 57, 1-50.

Carter, M.C., Foster, C.D., 2004. Prescribed burning and productivity in southern pine forests: a review. For. Ecol. Manage. 191, 93-109. 
Certini, G., 2005. Effects of fires on properties of forest soils: a review. Oecologia 143, 1-10.

Chokklingam, U., 1995. Recent disturbance-mediated vegetation change at Cape Cod National Seashore, Massachusetts. M.S. Thesis, University of Massachusetts, Amherst, MA. 127 pp. Choromanska, U., DeLuca, T.H., 2001. Prescribed fire alters the impact of wildfire on soil biogeochemical properties in a ponderosa pine forest. Soil Sci. Soc. Am. J. 65, 232-238.

Clarke, G.L, Patterson III, W. A., 2007. The distribution of disturbance-dependent rare plants in a coastal Massachusetts sandplain: Implications for conservation and management. Biol. Cons. 136, 4-16.

Covington, W.W., Sackett, S.S., 1986. Effect of periodic burning on soil nitrogen concentrations in ponderosa pine. Soil Sci. Soc. Am. J. 50, 452-457.

Davidson, E.A., Ackerman, I.L., 1993. Changes in soil carbon inventories following cultivation of previously untilled soils. Biogeochem. 20, 161-193.

Day, G.M., 1953. The Indian as an ecological factor in the northeastern forest. Ecology 34:329347.

DeLuca, T.H., Sala, A., 2006. Frequent fire alters nitrogen transformations in ponderosa pine stands of the stands of the inland Northwest. Ecology 87, 2511-2522.

Dunwiddie, P.W., 1994. Martha's Vineyard Landscapes: The Nature of Change. The Vineyard Conservation Society and Peter Dunwiddie, Vineyard Haven, MA. 60 pp.

Dunwiddie, P.W., Adams, M.A., 1994. Fire suppression and landscape change on outer Cape Cod: 1600-1994. Unpublished Report to the National Park Service, Cape Cod National Seashore, Wellfleet, MA. 94 pp.

Dunwiddie, P.W., Zaremba, R.E, Harper, K.A., 1996. A classification of coastal heathlands and sandplain grasslands in Massachusetts. Rhodora 98, 117-145. 
Dunwiddie, P.W., Patterson III, W.A., Rudnicky, J.L., Zaremba, R.E., 1997. Vegetation management in coastal grasslands on Nantucket Island, Massachusetts: effects of burning and mowing from 1982 to 1993. In: Vickery. P.D., Dunwiddie, P.W. (Eds.), Grasslands of Northeastern North America. Massachusetts Audubon Society, Lincoln, MA, pp. 85-98.

Dunwiddie, P.W., 1990. Rare plants in coastal heathlands: observations on Corema conradii (Empetraceae) and Helianthemum dumosum (Cistaceae). Rhodora 92, 22-26.

Eberhardt, R.W., Foster, D.R., Motzkin, G., Hall, B., 2003. Conservation of changing landscapes: vegetation and land-use history of Cape Cod National Seashore. Ecol. Appl. 13, 68-84.

Farnsworth. E.J., 2007. Sandplain plant life history traits as guides to multi-species management strategies for rare taxa. Biol. Cons. 160, 44-52.

Ferran, A, Delite, W, Valleho, V.R., 2005. Effects of fire recurrence in Quercus coccifera L. shrublands of the Valencia Region (Spain): II. plant and soil nutrient. Plant Ecology 177, 7183.

Fletcher, P., 1993. Soil survey of Barnstable County, Massachusetts. U. S. Department of Agriculture, Soil Conservation Service, Washington, D.C. 211 pp.

Forman, R.T.T. (Ed.), 1979. Pine Barrens: Ecosystem and Landscape. Rutgers University Press, New Brunswick, NJ. 601 pp.

Forman, R.T.T., Boerner, R.E., 1981. Fire frequency and the pine barrens of New Jersey. Bull. Torrey Bot. Club 108, 34-50.

Foster, D.R., Motzkin, G., 1999. Historical influences on the landscape of Martha's Vineyard. Harvard Forest Paper No. 23. Harvard Forest, Petersham, MA. 48 pp. 
Franklin, S.B., Robertso, P.A., Fralish, J.S., 2003. Prescribed burning effects on upland Quercus forest structure and function. For. Ecol. Manage. 184, 315-335.

Fuller, J., Foster, D.R., McLachlan, F, Drake, N., 1998. Impact of human activity on regional forest composition and dynamics in central New England. Ecosystems 1, 76-95.

Gundale, M.J., DeLuca, T.H., Fiedler, C.E., Ramsey, P.W., Harrington, M.G., Gannon, J.E., 2005. Restoration treatments in a Montana ponderosa pine forest: effects on soil physical, chemical and biological properties. For. Ecol. Manage. 213, 25-38.

Hatten, J., Zabowski, D., Scherer, G., Dolan, E., 2005. A comparison of soil properties after contemporary wildfire and fire suppression. For. Ecol. Manage. 220, 227-241.

Hieberg, S.O., Madgwick, H.A.I., Leaf, A.L. 1964. Some long-time effects of fertilization on red pine plantations. For. Sci. 10, 17-23.

Jordan, M.J., Patterson III, W.A., Windisch, A.G., 2003. Conceptual ecological models for the Long Island pitch pine barrens: implications for managing rare plant communities. For. Ecol. Manage. 185, 151-168.

Keetch, J.J., Byram, G., 1968. A drought index for forest fire control. Research Paper SE-38. U.S. Department of Agriculture, Forest Service, Southeastern Forest Experiment Station, Asheville, NC. 32 pp.

King, R., 2000. Effects of single burn events on degraded oak savanna. Ecol. Rest. 18, 228-233. Landis, R.M., Jurevitch, J., Fox, G.A., Fang, W., Taub, D.R., 2005. Variation in recruitment and early demography in Pinus rigida following crown fire in the pine barrens of Long Island, New York. J. Ecol. 93, 607-6-7. 
Lezberg, A.L., Buresch, K. Neill, C., Chase, T., 2006. Mechanical land clearing to promote establishment of coastal sandplain grassland and shrubland communities. Rest. Ecol. 14, 220232.

Liechty, H.O., Luckow, K.R., Guldin, J.M., 2005. Soil chemistry and nutrient regimes following 17-21 years of shortleaf pine-bluestem restoration in the Ouachita Mountains of Arkansas. For. Ecol. Manage. 204, 345-357.

Little, S., 1964. Fire ecology and forest management in the New Jersey pine region. Proc. Ann. Tall Timbers Fire Ecology Conf. 3, 34-59.

Little, S., 1974. Wildflowers of the pine barrens and their niche requirements. N.J. Outdoors 1, 16-18.

Little, S., 1979. Fire and plant succession in the New Jersey pine barrens. In: Foreman, R.T.T. (Ed.), Pine Barrens: Ecosystem and Landscape. Rutgers University Press, New Brunswick, N.J., pp. 297-314.

Little, S., Moore, E.B., 1949. The ecological role of prescribed burns in the pine-oak forests of southern New Jersey. Ecology 30, 223-233.

Lutz , H.J., 1934. Ecological relations in the pitch pine plains of southern New Jersey. Yale Univ. School of Forestry Bull. 38, 1-80.

MacKenzie, M.D., DeLuca, T. H., Sala, A., 2004. Forest structure and organic horizon analysis along a fire chronosequence in the low elevation forests of western Montana. For. Ecol. Manage. 203, 333-343.

Matlack, G.R., Good, R.E., 1990. Spatial heterogeneity in the soil seed bank of a mature coastal plain forest. Bull. Torrey Bot. Club 117, 143-152. 
Matlack, G.R., Gibson, D.I., Good, R.E., 1993. Regeneration of the shrub Galussacia baccata and associated species after low intensity fire in an Atlantic coastal plain forest. Am. J. Bot. $80,119-126$.

Melton, M., 1989. The Keetch/Byram Drought Index: A guide to fire conditions and suppression problems. Fire Manage. Notes 50, 28-34.

Mitchell, R.J., Auld, M.H.D., Hughes, J.M., Marrs, R.H., 2000. Estimates of nutrient removal during heathland restoration on successional sites in Dorset, southern England. Biol. Cons. 95, $233-246$.

Moore, E.B., Smith, G.E., Little, S., 1955. Wildfire damage reduced on prescribe-burned areas in New Jersey. J. Forestry 53, 339-341.

Motzkin, G., Foster, D.R., 2002. Grasslands, heathlands and shrublands in coastal New England: historical interpretations and approaches to conservation. J. Biogeogr. 29, 1569-1590.

NADP (National Atmospheric Deposition Program), 2006. NADP Program Office, Illinois State Water Survey, Champaign, IL. Site MA-01, Truro, MA, 1981 to 2005.

Neff, J.C, Harden, J.W., Gleixner, G., 2005. Fire effects on soil organic matter content, composition, and nutrients in boreal interior Alaska. Can. J. For. Res. 35, 2178-2187.

Neill, C., Von Holle, B., Kleese, K., Ivy, K.D., Collins, A.R., Treat, C., Dean, M., 2007. Historical influences on the vegetation and soils of the Martha's Vineyard, Massachusetts coastal sandplain: Implications for conservation and restoration. Biol. Cons. 136, 17-32.

Oldale, R.N., Barlow, R.A., 1986. Geologic map of Cape Cod and the Islands, Massachusetts: U.S. Geol. Survey Misc. Invest. Map I-763.

Patterson III, W. A., 2007. Managing fuels in Northeastern barrens. (www.umass.edu/nrc/nebarrensfuels/). 
Patterson III, W. A., Clarke, G.L., In press. Restoring barrens shrublands: decreasing fire hazard and improving rare plant habitat. In: Masters, R.E., Galley, K.E.M. (Eds.), Proceedings of the $23^{\text {rd }}$ Tall Timbers Fire Ecology Conference: Fire in Grassland and Shrubland Ecosystems. Tall Timbers Research Station, Tallahassee, FL.

Patterson III, W.A., Sassaman, K.E., 1988. Indian fires in the prehistory of New England, In: Nicholas, G.P. (Ed.), Holocene Human Ecology in Northeastern North America. Plenum Press, NY, pp.107-135.

Patterson III, W.A., Saunders, K.E., Horton, L.J., 1983. Fire regimes of Cape Cod National Seashore. U.S. Department of the Interior, National Park Service North Atlantic Region Office of Scientific Studies Report OSS83-1.

Patterson III, W.A., Saunders, K.E., Horton, L.J, Foley, M.K., 1985. Fire management options for coastal New England forests: Acadia National Park and Cape Cod National Seashore. In: Proceedings Fire Symposium and Workshop on Wilderness Fire Missoula, MT, November 15-18, 1983. Gen. Tech. Report INT-182, U.S. Dept. Ag. Forest Service, Intermountain Forest and Range Experiment Station, Ogden, UT, pp. 360-365.

Phillips, D.H., Foss, J.E., Buckner, E.R., Evans, R.M., FitzPatrick, E.A., 2000. Response of surface horizons in an oak forest to prescribed burning. Soil Sci. Soc. Am. J. 64, 754-760.

Reich, P.B., Abrams, M.D., Ellsworth, D.S., Kruger, E.L., Tabone, T.J., 1990. Fire affects ecophysiology and community dynamics of central Wisconsin oak forest regeneration. Ecology 71, 2179-2190.

Reiners, W.A., 1965. Ecology of a heath-shrub synusia in the pine barrens of Long Island, New York. Bull. Torrey Bot. Club 92, 448-464. 
Rhoades, C.C., Meier, A.J., Rebertus, A.J., 2004. Soil properties in fires-consumed log burnout openings in a Misouri oak savanna. For. Ecol. Manage. 192, 277-284.

Richter, D.D., Ralston, C.W., Harms, W.R., 1982. Prescribed fire: effects on water quality and forest nutrient cycling. Science 215, 661-663.

Robarge, W.P., Fernandez, I., 1986. Quality Assurance Methods Manual for Laboratory Analytical Techniques. U. S. Environ. Protection Agency and U.S. Dept. Agric. Forest Service Response Program, Corvallis, OR.

Schweitzer, D.F., Rawinski, T.J., 1988. Northeastern pitch pine/scrub oak barrens: element stewardship abstract, The Nature Conservancy, Arlington, VA.

Shelburne, V.B, Boyle, M. F., Lione, D.J., Waldrop, T.A., 2004. Preliminary effects of prescribed burning and thinning as fuel reduction treatments on the Piedmont soils of the Clemson Experimental Forest. In: Conner, K.F. (Ed.), Proceedings of the $12^{\text {th }}$ Biennial Southern Silvicultural Conf., Gen. Tech. Rep. SRS-71, U.S. Dept. Agric., Forest Service, Southern Research Station, Ashville, NC, pp 35-38.

Southwick, E.A.H., Turner, M.G., Mack, M.C., Chapin III, F.S., 2005. Postfire soil N cycling in northern conifer forests affected by severe, stand-replacing wildfires. Ecosystems 8, 163-181.

Sparks, J.C., Masters, R.E., Engle, D.M, Bukenhofer, G.A., 2002. Season of burn influences fire behavior and fuel consumption in restored shortleaf pine-grassland communities. Rest. Ecol. $10,714-722$.

Stevens, A., 1996. The paleoecology of coastal sand plain grasslands on Martha's Vineyard, Massachusetts. Ph.D. Thesis, University of Massachusetts, Amherst. 232 pp.

Stone, E.L., Kszystyniak, R. 1977. Conservation of potassium in the Pinus resinosa ecosystem. Science 198, 192-194. 
Stone, T.A., 1998. The land cover and land use of Cape Cod, 1951-1990. Environment Cape Cod 1, 35-49.

Swain, P.C., Kearsley, J.B., 2001. Classification of the Natural Communities of Massachusetts: Terrestrial Communities. Massachusetts Heritage and Endangered Species Program, Massachusetts Division of Fisheries and Wildlife, Westborough, MA. 97 pp.

Tiffney, Jr.,W.N., 1997. The role of nutrient-level control in maintaining and restoring lowland heaths: British and Northern European techniques of potential application in Northeastern North America. In: Vickery. P.D., Dunwiddie, P.W. (Eds.), Grasslands of Northeastern North America. Massachusetts Audubon Society, Lincoln, MA, pp. 69-78.

Vickery, P., 2002. Effects of prescribed fire on the reproductive ecology of northern blazing star, Liatris scariosa. Am. Midl. Nat. 148, 20-27.

White, A.S., 1983. The effects of thirteen years of annual prescribed burning on a Quercus ellipsoidalis community in Minnesota. Ecology 64, 1081-1085.

Winkler, M.G., 1985. A 12,500-year history of vegetation and climate for Cape Cod, Massachusetts. Quat. Res. 23, 301-312.

Woodwell, G.M., 1979. Leaky ecosystems: nutrient fluxes and succession in the pine barrens vegetation. In: Forman, R.T.T. (Ed.), Pine Barrens: Ecosystem and Landscape. Rutgers Univ. Press, New Brunswick, NJ, pp. 333-343. 
Table 1. Design of prescribed burn plots at the Cape Cod National Seashore, Truro, MA. Three replicate plots of each treatment, arranged in a randomized block, were established and first burned in 1986.

\begin{tabular}{cccc}
\hline Treatment & Burning time & Burning frequency & Number of times \\
& & & burned \\
\hline Control (no burning) & None & None & 0 \\
Spring burning & March or April & Every 4 years & 4 \\
Spring burning & March or April & Every 3 years & 5 \\
Spring burning & March or April & Every 2 years & 7 \\
Spring burning & March or April & Every year & 13 \\
Summer burning & July or August & Every 4 years & 4 \\
Summer burning & July or August & Every 3 years & 5 \\
Summer burning & July or August & Every 2 years & 7 \\
Summer burning & July or August & Every year & 13 \\
\hline
\end{tabular}


Table 2. Keetch-Byram Drought Index (KBDI) for different burn treatments in each year and mean KBDI for each burn treatment during the 13 years of this study.

\begin{tabular}{|c|c|c|c|c|c|c|c|c|c|c|c|c|c|c|c|c|}
\hline & & & & & & & & & & & & & & & $\begin{array}{c}\text { No. } \\
\text { Years }\end{array}$ & $\begin{array}{c}\text { No. } \\
\text { Years }\end{array}$ \\
\hline & & & & & & & & & & & & & & Mean & KBDI & KBDI \\
\hline Treatment & 1986 & 1987 & 1988 & 1989 & 1990 & 1991 & 1992 & 1993 & 1994 & 1995 & 1996 & 1997 & 1998 & KBDI & $>300$ & $>450$ \\
\hline $1 \mathrm{yr}$ & 167 & 488 & 128 & 145 & 166 & 495 & 367 & 436 & 386 & 466 & 461 & 424 & 124 & 327 & 8 & 4 \\
\hline $2 \mathrm{yr}$ & 167 & & 128 & & 166 & & 367 & & 386 & & 461 & & 124 & 257 & 3 & 1 \\
\hline $3 \mathrm{yr}$ & 167 & & & 145 & & & 367 & & & 466 & & & 124 & 254 & 2 & 1 \\
\hline $4 \mathrm{yr}$ & 167 & & & & 166 & & & & 386 & & & & 124 & 211 & 1 & 0 \\
\hline
\end{tabular}


Table 3. Results of overall one-way analysis of variance $(\mathrm{df}=8,18)$ to test the overall effect of treatments on soil variables in organic and mineral soil horizons. The level of significance was adjusted to $\alpha=0.0045$ to account for multiple ANOVAs. Soil variables that differed significantly with treatment are in bold.

\begin{tabular}{|c|c|c|c|c|}
\hline \multirow[b]{2}{*}{ Variable } & \multicolumn{2}{|c|}{ Organic } & \multicolumn{2}{|l|}{ Mineral } \\
\hline & $\mathrm{F}$ & $\mathrm{p}$ & $\mathrm{F}$ & $\mathrm{p}$ \\
\hline Organic horizon thickness & 6.30 & $<0.0006$ & & \\
\hline Bulk density & 12.06 & $<0.001$ & 1.06 & 0.434 \\
\hline $\mathrm{pH}$ & 7.51 & $<0.002$ & 8.14 & $<0.0001$ \\
\hline Exchangeable acidity & 6.90 & $<0.0003$ & 1.76 & 0.154 \\
\hline Exchangeable $\mathrm{Ca}^{2+}$ & 0.98 & 0.487 & 0.177 & 0.150 \\
\hline Exchangeable $\mathrm{Mg}^{2+}$ & 2.20 & 0.078 & 1.49 & 0.228 \\
\hline Exchangeable $\mathrm{K}^{+}$ & 2.16 & 0.084 & 0.84 & 0.577 \\
\hline Percent base saturation & 0.79 & 0.620 & 2.01 & 0.104 \\
\hline Percent C & 1.68 & 0.172 & 1.35 & 0.281 \\
\hline Percent N & 1.02 & 0.453 & 1.81 & 0.140 \\
\hline $\mathrm{C}: \mathrm{N}$ & 1.87 & 0.130 & 0.53 & 0.822 \\
\hline
\end{tabular}


Table 4. Results of two-way analysis of variance $(\mathrm{df}=7,16)$ to test the effects of the season and frequency and interactions between burning season and frequency on soil variables. Tests were conducted on only soil horizons and variables in which the overall effect of treatment was significant. The level of significance was adjusted to $\alpha=0.012$ to account for multiple ANOVAs. Soil variables that differed significantly with treatment are in bold.

\begin{tabular}{|c|c|c|c|c|c|c|c|c|c|}
\hline \multirow[b]{2}{*}{ Horizon } & \multirow[b]{2}{*}{ Variable } & \multicolumn{2}{|c|}{ Overall model } & \multirow{2}{*}{$\begin{array}{c}\text { Season } \\
\text { F }\end{array}$} & \multirow[b]{2}{*}{$\mathrm{p}$} & \multicolumn{2}{|l|}{ Frequency } & \multicolumn{2}{|c|}{ Season $\times$ Frequency } \\
\hline & & $\mathrm{F}$ & $\mathrm{p}$ & & & $\mathrm{F}$ & $\mathrm{P}$ & $\mathrm{F}$ & $\mathrm{P}$ \\
\hline \multirow[t]{4}{*}{ Organic } & Thickness & 4.54 & 0.006 & 1.51 & 0.0012 & 5.04 & 0.12 & 0.39 & 0.762 \\
\hline & Bulk density & 14.30 & $<0.0001$ & 15.58 & 0.012 & 18.38 & $<0.0001$ & 9.80 & 0.0007 \\
\hline & $\mathrm{pH}$ & 5.15 & 0.003 & 2.22 & 0.156 & 4.91 & 0.013 & 6.36 & 0.005 \\
\hline & Exchangeable acidity & 4.42 & 0.007 & 1.08 & 0.314 & 5.86 & 0.067 & 4.09 & 0.025 \\
\hline Mineral & $\mathrm{pH}$ & 7.34 & 0.0005 & 4.26 & 0.058 & 4.07 & 0.025 & 11.63 & 0.0003 \\
\hline
\end{tabular}




\section{Figure Legends}

Figure 1. The effect of prescribed burning time and frequency on soil organic (Oe) horizon depth and bulk density in organic and mineral horizons. Values are mean \pm 1 se. Means followed by the same letters were not significantly different $(\mathrm{p}<0.05)$.

Figure 2. The effect of prescribed burning time and frequency on soil $\mathrm{pH}$, exchangeable acidity, and percent saturation of base cations in organic $(\mathrm{Oe})$ and mineral horizons $(\mathrm{E}+\mathrm{A} 1)$ horizons. Values are mean \pm 1 se. Means followed by the same letter were not significantly different $(\mathrm{p}<0.05)$

Figure 3. The effect of prescribed burning time and frequency on soil cation stocks in organic (Oe) and mineral $(\mathrm{E}+\mathrm{A} 1)$ horizons. Grey bars are the organic horizon, dark bars are the mineral horizon. Values for total stocks are mean \pm 1 se. Mean total stocks followed by the same letter were not significantly different $(\mathrm{p}<0.05)$.

Figure 4. The effect of prescribed burning time and frequency on soil percent $\mathrm{C}$, percent $\mathrm{N}$, and $\mathrm{C}: \mathrm{N}$ molar ratios in organic $(\mathrm{Oe})$ and mineral $(\mathrm{E}+\mathrm{A} 1)$ horizons and total soil $\mathrm{C}$ and $\mathrm{N}$ stocks. Grey bars are the organic horizon, dark bars are the mineral horizon. Means are \pm 1 se. Means followed by the same letter were not significantly different $(\mathrm{p}<0.05)$. 